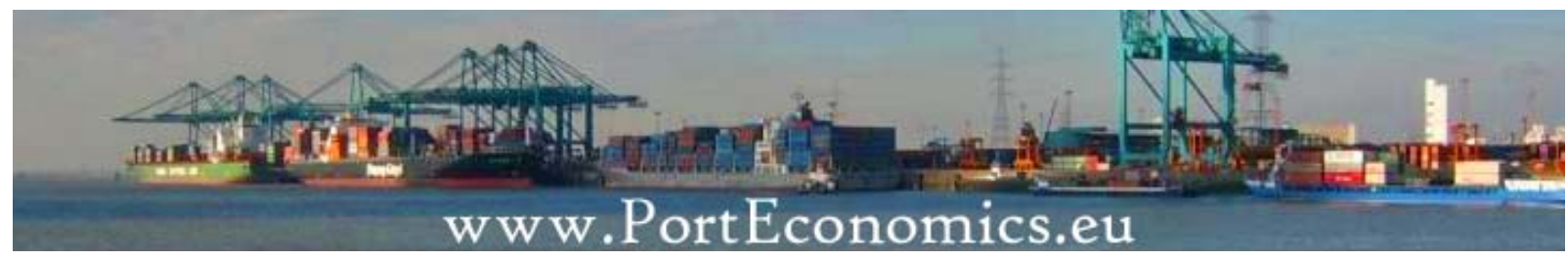

Concession Agreements and Market Entry in the Container Terminal Industry

Author(s): Pallis, A.A., Notteboom, T. and De Langen P.W.

A modified version of this paper had been published in:

Maritime Economics and Logistics, vol. 10, no. 3, pp. 209-228

This is a PDF file of an unedited manuscript that, in a modified form, has been accepted for publication or has already been published. For the convenience of the visitors of this site, an early version of the manuscript is provided. All legal disclaimers that apply to the journal pertain.

Please site this article as: Pallis, A.A., Notteboom, T. and De Langen, P.W. (2010). "Concession agreements and market entry in the container terminal industry". Maritime Economics and Logistics, vol. 10, no. 3, pp. 209-228.

This article was uploaded to www.porteconomics.eu

On: $30 / 01 / 2010$

Porteconomics.eu is a non-profit, web-based initiative aiming to advance knowledge exchange on seaport studies. Developed by researchers affiliated to various academic institutions throughout Europe, it provides freely accessible research, education and network-building material on critical issues of port economics, management and policies. 


\title{
Concession Agreements and Market Entry in the Container Terminal Industry
}

\author{
ATHANASIOS A. PALLIS
}

Department of Shipping Trade and Transport, University of the Aegean, 2 Korais St, Chios, 82100, Greece. E-mail: apallis@aegean.gr

\section{THEO E. NOTTEBOOM}

ITMMA - University of Antwerp, University of Antwerp, Keizerstraat 64, 2000 Antwerp, Belgium; E-mail: theo.notteboom@ua.ac.be

\section{PETER W. DE LANGEN}

Department of Applied Economics, Erasmus University Rotterdam, The Netherlands; department of Corporate Strategy, Port of Rotterdam Authority, Rotterdam, The Netherlands. E-mail: delangen@,few.eur.nl

Final version (May 2008)

Submitted for publication in Maritime Economics and Logistics The journal is available online at: www.palgrave-journals.com

\begin{abstract}
In this paper we describe the capabilities and strategies required for obtaining a concession to operate a terminal in a seaport. The extent to which concession procedures create entry barriers and lower the contestability of the market is assessed. Recent studies and policy initiatives have stressed the importance of lowering economic, institutional, and locational entry barriers in seaports. Concession procedures have an effect on market entry. Tenders may lower entry barriers, by ensuring transparency, restricting discrimination and exclusivity, and limiting concessions to certain periods. However, tender procedures may also introduce entry barriers in a number of ways, including the requirement of capabilities and track records to win a tender. The paper examines relevant empirical material of recently completed or intended concessions in major European ports to evaluate these issues.
\end{abstract}

Keywords: Ports, Market Entry, Concessions, Contestability

\section{INTRODUCTION}

This paper addresses the entry of private firms to markets in seaports through concessions. ${ }^{1}$ The port industry is characterized by substantial government involvement. Even though private terminal operators provide terminal services in most international seaports, governments usually retain the planning initiative (cf. Baird's (2002) study of privatization trends in the world's top-100 container ports; and ESPO's (2005) factual report). The UK is an exception, with predominantly private port-development initiatives ${ }^{2}$. Because governments mostly take 
the initiative for port development through a public Port Authority (PA), the dominant entry mode for private firms is through acquiring a concession to provide terminal services.

The focus of the study is concession procedures for port (container) terminals and the capabilities and strategies required for a successful tender. The paper explores the relevant theoretical issues and discusses the empirical regularities of concession procedures in certain ports. The purpose is to ascertain whether these procedures can create entry barriers and lower the contestability of the market.

In the following two sections, we review the importance of concessions in seaports and discuss some key theoretical issues with regard to entry in seaports. We then report our analysis of the procedures to grant concessions. Special attention is paid to the capabilities required to acquire concessions. Some important features of concessions of (a) the container terminals on the Maasvlakte 2 expansion of the Port of Rotterdam; (b) the recent tendering of the Muelle Prat Wharf container terminal in the Port of Barcelona; (c) the Deurganck Dock in the Port of Antwerp; and (d) the (still incomplete) moves towards the concessioning of the Container Terminal (SEMPO) of the Port of Piraeus are discussed in some detail. Other examples of concessions in North Africa and Latin America are briefly described. We then address the question whether the capabilities required for winning a concession favour consortia of established firms. The study concludes with a discussion of the role of the port authority with regard to concessions.

\section{THE NEED TO EVALUATE THE DOMINANT MODE OF ENTRY IN SEAPORTS}

Concessions are a trend that has been accelerated by the advent of containerization and the development of container terminals (Olivier et al, 2007) ${ }^{3}$. The financial resources required to invest in terminals to accommodate transport flows are one reason for the increasing involvement of private actors in the port market. This involvement has often been organized through concessions. The World Bank Private Participation in Infrastructure (PPI) Database (World Bank, 2007) reported 299 port projects involving private participation for the period 1990-2006. This number includes 151 direct concessions, 107 greenfield projects (several of which involved land concessions), 23 management and lease, and 18 divestiture projects. Of the 59 seaport projects reported in 2006, 40 were concessions.

In most cases, concessions are granted for specific terminals. Public port authorities (or occasionally other public agencies) generally develop a port master plan (detailing the layout of port development, such as breakwaters and terminal areas) and invest in general port infrastructure (port land, access roads and rail tracks). These port authorities grant private 
terminal operating companies concessions to operate a terminal and receive a concession fee from these companies. The responsibility for investment differs between concessions: in some cases, the public PA invests in quays and terminal area, while in other cases the private terminal operator has to make these investments. In such cases, the government usually still determines the main terminal characteristics such as size, location, and waterside and landside access.

This overview shows that entry to the terminal industry is strongly regulated and the prevailing entry mode is through acquiring a concession. Given these characteristics of the port industry, academics pay surprisingly little attention to concession procedures (Defillipi, 2004; Olivier 2005; Van Niekerk 2005).

Paying attention to entry barriers is particularly worthwhile given the ongoing consolidation and market concentration; the world's four largest container port operators (PSA, APM Terminals, Hutchison, and DP World) handle 38.1 percent of worldwide container traffic (see Table 1). In 2001, the market share of the top four operators was still below 30 percent.

\section{Table 1. Top 10 global container terminal operators' throughput}

According to the same report, local container terminal operators are often just as efficient as their global rivals; a well-run local terminal operator can frequently perform at the same level as a global operator located in the same region ${ }^{4}$.

In Europe, the non-carrier-based global container-terminal operators have expanded business considerably (cf. Slack and Frémont, 2005). It is estimated that the top six operators handled more than 70 percent of the total European container throughput in 2006 compared with 53 percent in 1998, illustrating the mature and consolidated nature of this market (ESPO, 2007). The consolidation trend in European increases the relevance of the issue of the contestability of the market (Notteboom, 2002). ${ }^{5}$

A relevant question is to what extent consolidation arises because of the entry conditions in the terminal industry. Do the global container-terminal operators have an edge in the bidding procedure related to concession agreements? Do concessions contribute to the unprecedented and extraordinary level of mergers and acquisitions (M\&A) in the container terminal industry? The relevance of these questions accounts for the recent investigations of concessions by the European Commission (2007). 


\section{Entry Barriers in Seaports}

Barriers to entry have long been studied in industrial organization. The Harvard structuralist school (Bain, 1956) defines a barrier to entry as anything that allows incumbent firms to earn surpranormal profits without the threat of entry. The Chicago school of efficiency (Stigler, 1968) identifies an entry barrier when the potential entrants face costs greater than a currently incumbent firm has had to bear. In contrast, the normative school (Von Weizsäcker, 1980) defines an entry barrier as an impediment to the flow of resources into the industry arising as a result of socially-excessive protection of incumbent firms. According to this account, a barrier is an undefined object whose presence is to be judged only in terms of its undesirable consequences for social welfare. These three major definitions of an entry barrier represent three distinct schools (Geroski et al, 1990), and have led to the broad and inclusive definition of a barrier to entry as anything that prevents an entrepreneur from instantaneously creating a new firm in a market, while a long run barrier to entry is a cost that must be incurred by a new entrant that incumbents do not (or have not had to) bear (Carlton and Perloff, 1994: 110).

Based on this broad understanding of barriers to entry, De Langen and Pallis (2007) identified a number of different entry barriers in seaports and summarized them in three categories. The first category is economic entry barriers that make entry unprofitable, and include structural cost advantages of incumbents; high switching costs; and the required investments (capital time and knowledge) of de novo firms to develop spatial and functional networks. The second category is legal and institutional entry barriers, such as entry permissions (that is, restricted entrance for historical, ideological or commercial reasons) and the conditions of exclusive concessions. Finally, there are locational entry barriers, for example the unavailability of land for entrants.

All three types of entry barrier can be substantial. The European Sea Ports Organisation (ESPO, 2004) conducted a survey that reported some factual information of European seaports of international importance (with a total annual traffic volume of not less than 1.5 million tonnes of freight or 200,000 passengers). This study showed the limited presence of intra-port competition (see: De Langen and Pallis, 2006). Access to the market of terminal services as well as such services as pilotage and other techno-navigational services is also often regulated. In addition, incumbents frequently have cost advantages, because new entrants would have to bear costs the incumbents have not had to meet. These characteristics make entry difficult. This situation may account for the relatively high profits in the terminal industry (Olivier, 2005). These characteristics might also explain why, in a situation of severe shortage of terminal capacity, as on the US west coast, the value of firms holding terminal 
concessions has risen substantially, while private investments in developing additional capacity have been relatively limited.

Given the fact that acquiring concessions is in many cases the only mode of entry to the terminal industry, the characteristics and the details of concessions, together with the procedures for awarding these concessions, stand to the fore in the analysis of entry in seaports.

\section{PROCEDURES AND CHARACTERISTICS OF CONCESSIONS}

The relevant issues concerning concessions in seaports include: the process of granting concessions; the criteria used to grant concessions; the duration of concessions; and the capabilities required to acquire concessions ${ }^{6}$.

\section{The process of granting concessions}

Terminal concession agreements may be awarded by several methods, including direct negotiation, selection from a qualified pool, competitive bidding, and a tender procedure. The difference between competitive bidding and a tender is that, in competitive bidding, a preferred candidate is selected and negotiations are held with this candidate, while in a tender all contractual agreements are detailed in advance. Empirical evidence (Textbox 1) suggests that governments, port authorities or other relevant policymakers may prefer competitive bidding since in this case the terms of a concession do not have to be specified in advance. Furthermore, policymakers can assess the interest of terminal operators or other companies for the concession in advance (Juan et al, 2004).

The EU legislation limits the scope for direct negotiations with only one candidate, as recently highlighted in the case of port reform in Greece. The concessioning process has been postponed twice owing to repeated industrial action by militant port labour (Pallis, 2007a). The initial intention of the Greek government to have direct negotiations with COSCO and the Chinese government had to be abandoned, because the European Commission ruled that such preferential treatment would breach the EU competition rules. Following this review, an international tender is the most likely approach.

The Barcelona and Rotterdam cases show that PAs can start with the process of granting concessions in advance of the construction of the site to be concessioned. The Barcelona Port Authorty decided to award the concession two years before the site became available. In 2005, the Port of Rotterdam Authority started the competitive bidding process procedure for operating the first Maasvlakte 2 container terminal to be operational in 2013. 
National and supranational legislation, port privatization schemes, and legal disputes with regard to irregularities in concession policy have made competitive bidding the most common current procedure in concession granting. Typically, a competitive bidding procedure for berths and terminals consists of two stages: qualification and selection. In both stages, potential candidates are evaluated against certain criteria.

\section{Textbox 1. The awarding of concessions: some examples}

\section{Criteria used to Evaluate Competing Bids for a Concession}

Candidates that want to compete for a concession first need to qualify for the bidding process. Qualification is typically based on proven business experience, technical solvency, and financial strength. The first stage in the bidding procedure reduces the number of candidates, and thus competition. At the same time, the risks of non-compliance by unreliable bidders is also reduced.

The experience of the candidate, for instance, can be demonstrated by their management of similar terminals in the same or other ports (Textbox 2). Candidates have to provide evidence of their experience in terminal operations.

In the selection stage, firms have to submit a bid for the concession. These bids are evaluated according to several criteria (see examples in Textbox 3). Apart from the price (an upfront payment and/or a lease rental, both discussed in the following section), the quality of the technical and operational proposal and the business plan are also evaluated. This business plan must show how the candidate aims to attract volume to the terminal. Although some requirements differ significantly from case to case, the following criteria are generally included; implementation details, financing details, a marketing plan, operational and management details, employment impact, an environment plan, and an organizational plan.

\section{Textbox 2. Measuring 'business experience' in the tendering procedure}

\section{Textbox 3. Criteria used to evaluate bids - some examples}

Capacity calculations have to demonstrate that the terminal layout will have the necessary capacity to accommodate the projected throughput. The marketing plan typically includes a market study that defines the demand of services for the terminal, including projections of yearly throughput for a number of years. 
Bidders frequently have to guarantee a certain minimum throughput per year. If this minimum is not met, the operator may have to pay a penalty, or a part of the terminal may even be withdrawn from the concession ${ }^{7}$. Throughput guarantees are especially required for the first years of a concession and are aimed at securing growth of throughput and market share. Furthermore, such guarantees can also be a criterion for awarding additional concessions to expand capacity. For example, Barcelona's tendering process stated that if the criteria of 80 percent capacity utilization in the first two years and over 50 percent transhipment were met, an additional concession to expand the terminal would be granted. Setting a high traffic guarantee limits potential bidders to the firms that operate container terminals in the port region (and can shift cargo volumes if they win the concession), carriers with sufficient container volumes or firms that have a satisfactory track record to attract liner-shipping companies.

In general, the bidding procedure also contains thresholds on the financial strength of the bidders. In the Barcelona case, financial solvency was associated with the financial track record and the capacity of the operator to maintain reserves of over 20 percent of total assets and over 30 percent of net fixed assets throughout the lifetime of the concession. Given the investments required, bidders need extensive resources. Consequently, an increasing number of terminals are awarded to consortia rather than individual terminal operators (Textbox 4). Global operators in some cases opt for a consortium with local partners to set up successful operations, but these global operators often aim to have a controlling stake in terminal operations $^{8}$. Consortia between terminal operators and shipping companies are also frequently observed. Such consortia combine the terminal handling capabilities of terminal operators and the volumes generated by the shipping lines.

\section{Textbox 4. The rise of consortia in concessioning procedures: some examples}

With regard to experience, the Port of Barcelona notes that: "It has been shown that investing in the resources and capital needed to operate a terminal is not enough to offset the company's lack of experience in the port sector, which is shaped by specific labour laws (...) the importance of large shipowners and the special legal status of ports and the collectives involved in the maritime industry" (Port of Barcelona, 2006: 7). The port of Barcelona needs a terminal with operational excellence in terms of both service quality and productivity. BPA argues that such high standards require extensive knowledge of the sector and experience in it.

Recent M\&A activity in both the container terminal operating business and liner shipping has affected (the strategies of) the contracting parties for concessions. Consequently, 
PAs include stipulations on M\&As in the concession agreements. Recently, the Antwerp PA introduced a controversial clause in some concession agreements requiring every M\&A activity involving the terminal concession to be reported to and approved by the PA (Textbox 5).

\section{Textbox 5. Dynamics in terminal consortia: the Deurganckdock case in Antwerp}

The concessions of the two Turkish ports of Izmir and Mersin (Textbox 6) provide an example of consortia that have managed to use financial solvency and experience to limit entrance to the market in spite of the expressed intentions of policymakers in the early stages of the process to ensure that competing companies would have opportunities for market entry.

Even though the quality of the business plan is invariably an important criterion, one might question whether the ability to attract cargo to the terminal can best be assessed on the basis of a business plan or from the price the candidate is willing to pay for the concession. In principle, a candidate who can attract more cargo will place a higher bid so the need to scrutinize and score business plans can be questioned.

\section{Textbox 6. Consortia and market entry - the case of Izmir and Mersin}

\section{Concessions and pricing}

The stipulations on the price bid depend on the price bidding system used (Goss, 1990). The alternatives available range from: (a) a given rent but minimal charges to (b) a maximum rent and the private operator's freedom to set charges. In the first option the port authority, or the competent government agency, aims to maximize the direct revenue. The payments are typically made on an annual basis. The second option concentrates on the interest of the port users and ensures price minimization.

Concession pricing may also consist of both an upfront payment and a cargo-handling fee, with seaport facilities awarded to the operator bidding the lowest cargo-handling fee (Demsetz auctions, after Demsetz, 1968). The latter fee cannot be lower than the floor the government decides. If two or more operators tie, then the operator offering the highest upfront payment wins the concession. In such Demsetz auctions, the setting of a cargo-handling fee is vital. Concessions are supposed, inter alia, to re-structure the market via the evaporation of the monopoly fee that the port operator extracts by fully exploiting monopoly powers. Whatever the floor cargo-handling fee is, the winning fee most probably equals it and the determining factor is commonly the upfront payment (Engel et al, 2004). This principle is particularly 
popular in developing countries where regulatory institutions are relatively weak (Flor \& Defillipi, 2003). An illustrative example of a Demsetz auction has been the new Callao Peru terminal concession (completed in 2006 - Textbox 7).

\section{Textbox 7. Demsetz auction at the Callao Peru terminal concession}

The economic rationale in all the pricing processes described above is that a concession is granted to those bidders willing to pay the highest access charges. The case described in Textbox 7 is one of those in which the government took advantage of conditions of trade booming and lack of container terminals concessions to be won and operated in the particular region, and set the floor fee at remarkably low levels (note: this floor can even be set below the ports average cost). Still, global operators jockeyed to match this floor-fee.

But as it has been assessed elsewhere (Engel et al, 2004) in the case of a Demsetz auction the ex-post market structures will be determined by the floor fee. In particular, concessions like the preceded one might create barriers for those not having developed networks of business organizations and resources to advance a vertically-integrated market. As potential bidders pursue aggressive company strategies - because they seek more (container) terminals to operate but face a short supply of availability and concessioning of such terminals - it is logical to expect the winner of concessions to be one that has:

(a) ex-ante established vertical-integration type relationships with the relevant downstream shipping market, or

(b) explored the potential of developing ex-post such vertical integration, or

(c) a major other (than pure economic) reason to be present in the specific port (that is, prestige).

Besides, as Engel and colleagues (2004) assert, setting a low floor fee diminishes the operator's potential profit margin. To overcome this, the company gaining the concession may opt for arrangements that integrate vertically into shipping and may become involved in sabotage as a means of driving competitors out of business. Sabotage might involve the slowing down of loading or unloading processes and the manipulation of the procedure for awarding slots in the port to arriving ships in a way that increases the capital and operational costs for the non-integrated shipper, so that companies would be obliged to send cargo using a specific integrated operator, logistics, and shipping companies. Entry barriers remain high, since non-integrated bidders competing for access in the port market cannot follow in offering abnormal upfront payments to win the concession and enter the specific market. Notably, the 
regulatory framework might determine whether vertical integration practices are allowed to develop or not.

On the other hand, the floor fee might be high enough for the winner to choose to avoid the inefficiencies of vertical integration and extract monopolistic rents. In this case, the competition in the port services market remains low; despite the concession process, incumbent firms continue to earn surpranormal profits without the threat of entry.

There is, however, a threshold fee such that the operator prefers separation if the floor is set higher or chooses vertical integration if it is set lower. To achieve this optimum level, which stands as second price (because the user of the port will not pay the lowest possible handling fees) the regulatory framework needs to be adjusted accordingly. Banning or controlling vertical integration-related practices lowers this threshold fee (not least because of the probability of paying relevant punishment costs should underhand agreements be detected and therefore prosperity increases (since port users pay lower fees; and entry barriers are lower).

\section{Duration of concessions}

A third issue is the appropriate duration of a concession. Terminal operators are in favour of long concessions (FEPORT, 2005). Clearly, the length of a concession varies with the need for immovable investments. To give an example: in the (twice proposed but rejected) proposal for an EU directive on market access in European ports, the European Commission suggested a maximum duration of 8 years when there are no investments, 12 years in the case of significant investments in movable assets, and 30 years in the case of significant investments in immovable assets. Port authorities and operators argued for a 10/15/45 clause and shipowners for 8/15/36 (Pallis, 2007b). A number of PAs have worked out a system that helps them determine the concession term based on the initial investments of the concessionaire (see example in Table 2).

Port authorities have three reasons for aiming at relatively short concessions. First, especially in unstable economic and political countries, the risk valuation of private companies will be high. Consequently, the price firms are willing to pay for a concession will only increase marginally when the concession period is lengthened. From a revenue-maximizing point of view, relatively short concessions are more attractive for port authorities than longer ones. Second, long concession periods reduce the opportunities for effective port redevelopment, because concession holders will seek high compensation should their terminal operations be affected by port-redevelopment projects. Third, short concession periods reduce entry barriers since opportunities to enter the market are more frequently available. 
The conditions for the renewal of a concession are a key issue. On the one hand, if the concession agreement does not stipulate the conditions for renewal, the concessionaire will typically cease all investments in the last years of the concession. Lower terminal efficiency and a suboptimal use of the land can ensue. On the other hand, clauses regarding renewable concessions result in a bidding procedure that offers a comparative advantage to the existing concessionaire vis-à-vis potential entrants. This existing concessionaire is likely to have an advantage deriving from experience, market knowledge, and an established customer base. Therefore, PAs have to make a trade-off between securing market entry and binding efficient terminal operators.

\section{DO CONCESSION PROCEDURES FAVOUR GLOBAL TERMINAL OPERATORS?}

As a response to the concentration in container shipping, a number of terminal operators have expanded internationally. Through such growth strategies, today's global operators have progressed from local/regional players to the global market. The ability to enter new markets is a key issue in such a strategy. The preceding analysis shows global terminal operators (mostly in consortia) are well positioned in the competition for terminal concessions.

First, the move towards transparent and open concession procedures reduces the protection of local terminal operators. The protection policy of local PAs gave local firms a uncontestable advantage. Local players who used to rely on the protection of local authorities now face competition from experienced global players who seek to secure capacity all over the world. In the best-case scenario, the local players could engage in a joint venture to operate the concession. In other cases, local players are taken over by global players or forced to focus on niche markets.

Secondly, port liberalization has facilitated the expansion of well-funded global players with specific expertise. The scale of operations of the gobal operators has created substantial surplus resources that allow them to outperform rival companies financially in the bidding procedures for new terminal operations. The sound financial status facilitates the movement of resources to wherever they generate the highest yields. Since these operators often manage more than one terminal in the same port region, they are to some extent able to redistribute 
cargo flows among their terminals to comply with the minimum throughput guarantees as stipulated in the respective concession agreements ${ }^{9}$.

Third, in the current market situation, the global players seem to be best placed to meet the high capital requirements and required capabilities in the competition for concessions. For example, PSA first built a stronghold in Singapore, its home base, before taking the step towards global scale and coverage. The critical mass and its focused strategy at Singapore enabled PSA to develop exceptional competencies in terminal handling. Once the company had established itself as an international benchmark, the company's ambitions went global through a mixed strategy of organic growth (new terminals) and acquisitions (for example, HesseNoordNatie in Belgium in 2002) backed up by a sound financial position. This development was accelerated by increased competition at its Singapore terminals, not least from newcomer Tanjung Pelepas in Malaysia.

\section{CONCLUSIONS AND POLICY DISCUSSION}

This combination of empirical data and conceptual analysis makes it clear that, even though concessions may improve market access, many concession processes demand capabilities that limit considerably the pool of potential candidates for entry.

The criteria commonly used in evaluating competing bids for a concession, as well as issues related to the pricing and the terms of a concession (that is, required cargo guarantees, duration, terms of exit and renewal), create barriers to entry. In the competition for concessions, specific terminal capabilities, control over container flows, and a solid financial position are crucial. In practice, these requirements advance the presence of (consortia of) established firms. Thus, unintentionally concession practices often discourage entry from newcomers to the industry.

Concession agreements are probably the most important tool available to landlord port authorities in dealing with the terminal-operator industry. The design of the concession agreement is crucial (Notteboom, 2007). Port authorities can retain some control of the organization and structure of the supply-side of the port market, while optimizing the use of scarce resources such as land through the design of a concession agreement, its regulatory regime, the tariff regime and the way the concession is awarded.

First, through specifications in concession agreements, port authorities can shape the structure of the terminal handling business in the port area. To widen the private sector's participation and provide competition, the PA can stipulate that an operator may not participate 
in more than one contract at the same port. In smaller ports, a concession agreement could state that no other stevedore may handle containers over berths in the same port. Port authorities can partially design the intra-port market configuration they prefer through the bidding procedures and concession agreements used. A port authority may have good reason to opt for a market configuration of only one or two container terminal operators within a specific port area - for example, to provide a better answer to carrier power and carriers' demands and to guarantee a larger financial base for investments in expensive terminal infrastructure.

Secondly, port authorities can set the term of a concession. In general, the duration of a concession varies with the amount of the initial investment required, compliance with the development policy of the port and land lease, and other easement rights. The duration of the agreement is of crucial importance to both terminal operators and port authorities. In general, long-term agreements allow private port operators to benefit from learning-by-doing processes and to achieve a reasonable ROI. Port authorities try to find a balance between a reasonable payback period for the investments made by terminal operators on the one hand and a maximum entry to potential newcomers on the other. Since long-term agreements limit market entry, intra-port competition will only take place among the existing local port operators. However, even when concession periods are long, new players can still enter the market through a merger or the acquisition of a local operator or when a long-term concession or lease of a new terminal expansion is allocated to them.

Thirdly, the landlord PA can indicate upfront a minimum throughput to be guaranteed by the concessionaire (especially in the case of existing berths/terminals). Throughput guarantees should secure a reasonable level of land productivity. There is also a potential impact on the terminal market structure within the port. Hence, stringent demands regarding the use of space by the concessionaires can lower the entry barriers to newcomers. The PA could withdraw underutilized parts of the terminal from the concession. These kinds of stipulation in concession agreements contribute to improved contestability in the containerhandling industry (Notteboom, 2002).

Finally, there is the issue of concession fees. High fees, royalty payments, and revenuesharing stipulations are detrimental to the terminal operator's ROI and could decrease the investment potential of the incumbent terminal operator and discourage future investors. Low payments could negatively affect the revenue base of the PA.

With the emergence of global terminal-operator groups and shipping lines, port authorities are confronted with powerful and footloose players. Uneasiness concerning traffic losses might make port authorities less vigilant and strict with regard to the interpretation and enforcement of the rules in the concession agreement. Global terminal operators typically 
possess a market-based edge in the bidding procedure for concessions and their market share in terminal throughput is therefore likely to increase in the future. The market-based strengths of global terminal operators relate to their financial strength and their proven record in terms of terminal development and expertise. These two elements play a crucial part in the bidding procedure.

Concession agreements increasingly take the form of performance-based contracts to create incentives for the terminal operator to act in the PA's interest. The dynamics in the port environment induce port authorities to evaluate continuously the effectiveness of their concession policies in the light of market trends and advances in the legal framework.

Since concession procedures and the associated capability requirements create entry barriers for newcomers, policies aiming to lower these barriers may be relevant. Relevant initiatives should address such issues as optimum duration, prices, and processes. Clear definition of inter- and intra- port competition rules, the downplay of 'strategic factors' for winning a concession, and not least the currently neglected issues of incumbent firms' practices during the last years of the concession period and the details of market exit also deserve attention. The same applies to rent-seeking practices of 'local partners' and the stability of consortia involved in tendering. These factors all represent avenues for further research, Given the fact that granting concessions is one of the most influential port-development characteristics, the relevance and the necessity of such research is evident.

\section{REFERENCES}

Bain, J (1956). Barriers to New Competition. Cambridge. Massachusetts: Harvard University Press.

Baird, AJ (2002). Privatization trends at the world's top-100 container ports. Maritime Policy and Management 29(3), 271-284.

Carlton, D and Perloff, J (1994). Modern Industrial Organization. New York: HarperCollins College Publishers.

De Langen, PW and Pallis, A.A. (2006). The effects of intra-port competition, International Journal of Transport Economics 33(1): 69-86.

De Langen, PW and Pallis, AA (2007). Entry Barriers in Seaports. Maritime Policy and Management 34(5): 427-440.

Defilippi, E (2004). Intra-Port Competition, Regulatory Challenges and the Concession of Callao Port. Journal of Maritime Economics and Logistics 6(4): 279-311.

Demsetz, H (1968). Why Regulate Utilities. Journal of Law and Economics 11(1): 55-66.

Drewry Shipping Consultants (2007). Annual Review of Global Container Terminal Operators 2006. London: Drewry.

Engel, EMRA, Fischer, RD and Galetovic A. (2004). How to Auction a Bottleneck Monopoly When Underhand Vertical Agreements are Possible. Journal of Industrial Economics 52(3): 427-455. 
ESPO (European Sea Port Organisation) (2004). Impact assessment of the Proposal for a Directive of the European Parliament and of the Council on Market Access to Port Services Mimeo. Brussels: ESPO.

ESPO, (2005). European Ports-Factual Report. Brussels: ESPO.

ESPO, (2007). Annual Report. Brussels: ESPO.

European Commission (2007). Communication on a European Ports Policy, COM(2007) 616 final. Brussels: European Commission.

FEPORT (2005). FEPORT Position paper presented at the public hearing of the European Parliament and the European Commission. Brussels: FEPORT.

Flor, L and Defilippi, E (2003). Port Infrastructure: An Access Model for the Essential Facility. Maritime Economics and Logistics 5(2): 116-132.

Geroski, P, Gilbert, R and Jacquemin, A (1990). Barriers to entry and strategic competition. London: Taylor and Francis.

Gilman, S (2004). Sustainability and national policy in UK port development, Maritime Policy \& Management 30(4): 275-291.

Goss, R (1990). Economic policies and seaports - part 3: Are port authorities necessary? Maritime Policy and Management 17(3): 257-271.

Grant, RM (1991). The resourced-based theory of competitive advantage: implications for strategy formulation. California Management Review 33(3): 114-135.

Guasch, JL (2004). Granting and Renegotiating Infrastructure Concessions: Doing it Right. Washington: The World Bank.

Guasch, JL, Laffont, JJ and Straub, S (2006). Renegotiation of Concession Contracts: A Theoretical Approach. Review of Industrial Organization 29(1): 55-73.

Juan, C, Olmos, F, Casasus, T, Pérez, JC, García, L, Feo, M, Monfort, A, Pérez, E and Torregrosa, A (2004). Concession Agreements in the Shipping Industry. 8th Annual International Conference on Real Options, Montréal Canada, June 17-19, 2004.

Kerf, MR, Gray, D, Irwin, T, Levesque, C and Taylor R. (1998). Concessions for Infrastructure: A Guide to their design and award. Paper No. 389. Washington, D.C.: World Bank.

Moglia, F and Sanguineri, M (2003). Port Planning: the Need for a New Approach? Journal of Maritime Economics and Logistics 5(4): 413-425.

Musso, E, Ferrari, C and Benacchio, M (2001), Co-operation in maritime and port industry and its effects on market structure, 9th World Conference on Transport Research (proceedings in CD-Rom format), Seoul, Korea, July 2001.

Notteboom, T (2002). Consolidation and contestability in the European container handling industry. Maritime Policy and Management 29(3): 257-269.

Notteboom, T (2007). Concession agreements as port governance tools. In: Brooks, MR and Cullinane, K (eds.), Devolution, port governance and performance. London: Elsevier. pp. 449-467.

OECD (2006). Global Forum on Competition: Roundtable on Concessions, Contribution from Turkey. Paris: OECD.

Olivier, D (2005). Private entry and emerging partnerships in the container terminal operations: Evidence from Asia. Maritime Economics and Logistics 7(2): 87-115.

Olivier, D, Parola F, Slack, B and Wang JJ (2007). The Time Scale of Internationalisation: The Case of the Container Port Industry. Maritime Economics and Logistics 9(1): 1-34.

Pallis, AA (2007a). Whither Port Strategy? Theory and Practice in Conflict, In: idem (ed.) Maritime Transport: the Greek Paradigm. London: Elsevier. pp. 345 -386. 
Pallis, AA (2007b). EU Port Policy Developments: Implications for Port Governance, In: Brooks, MR and Cullinane, K (eds.), Devolution, port governance and performance. London: Elsevier. pp. 161-176.

Port of Barcelona, (2006). Bid specifications for the Muelle Prat Wharf Container Terminal concession. Barcelona: BPA

Port Strategy (2006). No way to do business. August 2006.

Slack, B and Frémont, A (2005), Transformation of port terminal operations: from the local to the global. Transport Reviews, 25(1): 117 - 130.

Stigler, G (1968). The Organization of Industry/ Homewood, Ill: Irwin.

Van Niekerk, HC (2005). Port Reform and Concessioning in Developing Countries. Maritime Economics and Logistics 7(2): 141 - 155.

Von Weizsäcker, CC (1980). Barriers to entry: a theoretical treatment. Berlin: Springer Verlag.

World Bank (2007), Private Participation in Infrastructure (PPI) database. $<$ http://rru.worldbank.org/PPI $>$, viewed 22 April, 2007. 
Table 1. Top 10 global container terminal operators' throughput (in 2006; equity based)

\begin{tabular}{|c|c|c|c|c|}
\hline Ranking & Operator & $\begin{array}{l}\text { Equity } \\
\text { (million) }\end{array}$ & TEU throughput & $\begin{array}{l}\text { percentage share of } \\
\text { world throughput total }\end{array}$ \\
\hline 1 & PSA Corporation* & & 41.2 & 9.3 \\
\hline 2 & APM Terminals & & 32.4 & 7.4 \\
\hline 3 & Hutchison $\mathrm{PH}^{*}$ & & 30.8 & 7.0 \\
\hline 4 & DP World** & & 26.2 & 5.9 \\
\hline 5 & Evergreen & & 8.1 & 1.8 \\
\hline 6 & Cosco Group & & 7.9 & 1.8 \\
\hline 7 & Eurogate & & 6.6 & 1.5 \\
\hline 8 & HHLA & & 6.0 & 1.4 \\
\hline 9 & OOCL*** & & 4.8 & 1.1 \\
\hline \multirow[t]{4}{*}{10} & APL & & 4.6 & 1.0 \\
\hline & Top-10 global operators & & 168.6 & 38.2 \\
\hline & Other global operators & & 33.0 & 7.5 \\
\hline & Local Operators & & 239.7 & 54.3 \\
\hline
\end{tabular}

* PSA acquired 20 percent of HPH in 2006; figures reflect this.

** DPW acquired P\&O Ports in 2006.

*** OOCL has since sold most of its terminal interests

Source: Drewry, 2007.

\section{Textbox 1. The awarding of concessions: some examples}

Port of Antwerp: The concessioning with respect to the Deurganckdock in Antwerp followed a competitive bidding procedure. However, it was clear from the start that the Antwerp Port Authority (APA) was eager (a) to grant the two terminals (east and west side of the dock) to different operators to enhance intra-port competition and (b) to give two incumbent firms (P\&O Ports and PSA Hesse Noordnatie) the opportunity to further develop their business in Antwerp. This latter objective resulted in an unusual arrangement in the initial concession agreement: should one contender, Maersk Line meet certain volume growth conditions, then Maersk (through APM Terminals) would be granted an exclusive terminal in 2007, with the site 'to be defined' at the Deurganck Dock. This arrangement did not materialize, partly owing to the development of APM Terminals in the outer port of Zeebrugge, a booming coastal port in Belgium.

Port of Rotterdam: In the case of the two Maasvlakte 2 container terminals, the Port of Rotterdam Authority used two methods. One terminal was awarded to APM Terminals, following direct negotiations between the PA and AMP terminals. A second terminal was awarded via competitive bidding, in which interested firms had to submit bids. In the last phase of this procedure two candidates remained: a combination of MSC and PSA and a consortium of DP World, CMA CGM and the New World Alliance. The latter eventually won the concession and is expected to start operations at its Rotterdam World Gateway in 2013.

Port of Barcelona: In the case of the Muelle Prat Wharf container terminal, the call for tenders was open to all, and the Barcelona Port Authority (BPA) proceeded to a contract with the 'winner' of the tender procedure.

Port of Piraeus. In 2006, the Greek government (as the major shareholder) held direct talks with several terminal operating companies (COSCO, HPH, DP World, APM Terminals, MSC, and ZIM) and governments (China, Korea) that were interested in investing in the Greek port. Reportedly, following intergovernmental talks between the Greek and the Chinese governments, COSCO was regarded as a likely partner for terminal investments in Greece's largest container termninal (Piraeus), the aim being to develop Piraeus as a transhipment hub in East Mediterranean. Following objections by the European Commission, as regards the concessioning of seaport terminals on the basis of intergovernmental decisions - rather than following a competitive bidding - the process was abandoned. In December 2007, the government returned with a call for tender that was open to all. The process is still incomplete, with COSCO and Hutchinson (as a consortium leader) being the only two bidding companies. 


\section{Textbox 2. Measuring 'business experience' in the tendering procedure}

The tendering of the container terminal in the Port of Barcelona was only open to companies with experience in managing a terminal handling over 500,000 TEU for successive years or to joint ventures with at least one partner with such experience who agreed to take a minimum 25 percent stake in the concessionary company. Experience of handling one million TEU per year has been reported as the threshold to be set for participating in the future concession process of the Piraeus port. ${ }^{10}$ With regard to technical solvency, in the Barcelona case the call added 'horizontal integration' to 'loading, unloading, stevedoring, transhipment' and 'warehousing' as the required 'basic port handling services'.

According the Port of Rotterdam Authority, 'filling capability gaps in logistics, broadening the geographical markets served, and expanding terminal networks' were core criteria in the competitive bidding procedure for the Maasvlakte 2 concession.

\section{Textbox 3. Criteria used to evaluate bids: some examples}

The Port of Rotterdam Authority used four criteria to evaluate bids: the financial bid (40 percent), the business plan (25 percent), the sustainability of the bid (20 percent), and the terminal concept (15 percent). Aspects of sustainability included the 'modal split' (percentages of rail, inland shipping, and truck in hinterland transport), emissions from the terminal, and the overall vision of the bidders with regard to sustainable enterprise ${ }^{11}$. Financially, the bids were assessed in terms of volume guarantees in addition to the usual revenues from land rent and harbour dues. The business plan was evaluated specifically with regard to the position of Rotterdam in the shipping and port network of the consortia and the degree to which the terminal would attract new cargo to Rotterdam. In the technical field, the efficiency of operations and the quality of the terminal were evaluated.

As in the Rotterdam case, the concession in Barcelona's port followed evaluation of the business plan (30 percent), the technical and operational proposal (40 percent), and the financial bid (30 percent). The intentions regarding the concession of the Piraeus container terminal and the Antwerp Deurganckdock are also related to experience, capacity to invest, the business plan, and the financial bid.

\section{Textbox 4. The rise of consortia in concessioning procedures: some examples}

TANGERMED - Morocco: Consortia are involved in developments in some North African terminals aiming to become a major Mediterranean hub ${ }^{12}$ and challenge European ports. The $€ 1 \mathrm{bn}(\$ 1.4 \mathrm{bn})$ concession of two terminals of the new TangerMed port indicates that, given the size of the concessions, local players prefer to participate in consortia that guarantee financial and technical solvency, while global players also strive to develop consortia; though in the latter case this decision might extend well beyond such financial and/or technical considerations. The concession of the two new TangerMed container facilities resulted in bids by consortia combining local players with the major companies. The final round of bidding for a second terminal facility of $1.5 \mathrm{~m}$. TEU capacity and 40 acres of yard space was between two consortia. The winner was the consortium of the terminal operator Eurogate/Contship, shipowners MSC, CMA-CGM and the local company Comanav; the loser was a consortium that combined the local player IMTC and Hutchinson. The final round of the first facility concession (2002), which mirrors the dimensions of the second one, was between a consortium formed by a global player (APM Terminals), in partnership with a local company (Akwa Holding) and another that included major shipping names — Evergreen, CMA-CGM and P\&O Ports.

MAASVLAKTE 2 - Rotterdam: The case of the competitive bidding procedure for the Maasvlakte 2 container terminal is similar. Fourteen shipping and stevedoring companies expressed interest. The size of the terminal (a 4 million TEU, 146 hectare site, with a depth of $20 \mathrm{~m}$ for larger vessels, a quay wall of around 2,350 m., including space for the barge and feeder handling, and a dedicated rail terminal) contributed to the formation of consortia. Six consortia, including, some firms that have major terminals in the rival port Antwerp (the combination PSA/MSC, DP World) submitted bids. Notably, the concession of the first phase of the Euromax terminal at the existing Maasvlakte site (1,500 $\mathrm{m}$ of quay wall, 2.3 million TEU capacity, operational in the second half of 2008) was also awarded to a consortium rather than a single firm: ECT (part of the Hutchison PH group) with 51 percent and the CKYH alliance (Cosco, K-Line, Yang Ming and Hanjin) with 49 percent. 


\section{Textbox 5. Dynamics in terminal consortia: the Deurganckdock case in Antwerp}

The initial plan was that the first and the second phase (west) would incorporate the building of a dedicated terminal allocated to the joint venture Hessenatie/MSC with an annual capacity of at least two million TEU. The second phase (east) was granted to Hessenatie to accommodate container flows generated by the CP Ships group (CAST, Canmar, Contship and Lykes Lines). The concession for the third phase (west) was granted to the combination of Hessenatie / Noord Natie, while the Board of the Antwerp PA awarded the concession for the third phase (east) to P\&O Ports. In 2003 MSC, the largest customer of the Antwerp port (1.8 million TEU in 2003 and 3.6 million TEU in 2007) announced there would be no move of activities from the right to the left bank. The MSC shipping company opted for handling its vessels on its own "MSC Home Terminal" located at the Delwaide Dock on the Right Bank behind the locks in collaboration with PSA HNN (50-50 joint venture). In September 2003, the Board of Directors of the Antwerp PA gave the green light for the further implementation of the decisions and options in connection with the concessions to the Deurganck Dock and its reconfiguration, partly in reaction to the decision of MSC. The main candidates for the terminals were PSA HNN, Maersk, Eurogate and P\&O Ports. After a competitive bidding procedure, the incumbent firms P\&O Ports and PSA HNN acquired terminal concessions. The implementation of the decisions taken implied that the western side of the Deurganck Dock would become available for PSA HNN. Total capacity could reach 3.75 million TEU. The first part of the terminal became operational at the end of 2005. The eastern side of the Deurganck Dock was awarded to the P\&O Ports consortium 'Antwerp Gateway' (40 years concession). Initially Antwerp Gateway was a joint venture between P\&O Ports (67.5 percent), P\&O Nedlloyd (25 percent) and Duisport (7.5 percent - the German inland port of Duisburg). The first phase of the new terminal commenced operations in September 2005. When fully operational, the terminal, with a total development cost estimated at $€ 450$ million, will add over 3.5 million TEU.

Since 2003, the year the concessions were granted, the market has changed quite significantly. First, the takeover of P\&O Ports by DP World meant that the PA was suddenly confronted with a new operator. Second, the takeover of P\&O Nedlloyd by Maersk meant that the AP Moller/Maersk group became a shareholder in Antwerp Gateway. Cosco Pacific and CMA CGM came in as partners a few years ago. In mid 2007, ZIM Port Logistics took over the 20 percent shareholding of Maersk in Antwerp Gateway, leading to a complex shareholder structure that has little in common with the initial one: DP World 42.5 percent, ZIM Port Logistics 20 percent, Cosco Pacific 20 percent, CMA CGM 10 percent, Duisport 7.5 percent (situation mid 2007). Third, PSA HNN renamed its Deurganck dock terminal 'Antwerp International Terminal' (AIT)'. PSA HNN has managed to lock in three members of the CKYH alliance (with the exception of Cosco) under the terms of a joint venture making use of two berths in the Deurganck dock. All the market changes listed above meant that the evolving consortia exerted an almost constant pressure on the PA to renegotiate the concession agreements.

\section{Textbox 6. Consortia and market entry: the case of Izmir and Mersin}

The TCDD (The State Railway Company, General Directorate of the State Railway Administration of Turkey) started a concession process in Turkey with the aim of avoiding dominant positions in the provision of container-handling services, and ensuring intra-port competition. Consequently, TCDD has developed two separate packages in both Izmir and Mersin to be operated by two different undertakings and/or associations of undertakings

When successful bidders were reported to the Competition Board, it ruled that any one of the successful bidders could acquire the right to operate the entire Mersin port. As a result, the consortium PSA and (Turkey's) Akfen Joint Venture, which offered the highest bid of $\$ 755$ million (reportedly paid in advance $)^{13}$, obtained a concession to operate the port for 36 years. The Competition Board, in contrast with its initial opinion to disallow a single undertaking to obtain the right to operate Mersin port, allowed the acquisition. This was because of the existence of provisions in the contract for transfer of the right to operate the port (including: compulsory investments within the first 5 years that would increase containerhandling performance by 2.25-3.2 times, performance criteria to be satisfied while compulsory investments are undertaken in order to avoid failure in services given in the port). The Competition Board advocated that these contract provisions would substitute the expected benefits of establishing intra-port competition as foreseen in its initial Opinion, arguing that the latter favoured the creation of intra-port competition only as a result of the initial strict attitude that no regulatory arrangements could be applied in ports (OECD, 2006). In fact, the Turkish state was even considering offering the Izmir port to the same consortium, again ignoring its statement regarding intra-port competition. In the end, Hong Kong's Hutchison group and its 
consortium partners, Turkey's Global Investment Holding and Turkish port operator EIB won the bid for operating the port of Izmir with an offer of \$1.275 billion for 49-year operating rights. Turkey's Celebi Holding, the only single-entity bid, and another consortium including the Turkish port operator Alsancak and the Egyptian-owned cement firm Baticim Bati were ignored. ${ }^{14}$ Looking to the future, independent actors (that is, the Turkerler Group) are seeking global partnerships in order to run another Turkish port (Derince) even though in that case they have submitted the highest bid in a tender for the operating rights.

\section{Textbox 7. Demsetz auction at the Callao Peru terminal concession}

Apart from the upfront payment, the government dictated the terminal handling charges capable of being levied in conjunction with the concession, setting a $\$ 69$ to $\$ 90$ per TEU range for a full cycle move from hold to gate and vice-versa. Bidders had to fix a charge in this range in the initial part of the bid process; to stand any chance of winning the concession, the 69 level was seen as the tariff that had to be offered. Indeed, the three first-ranked bidders (P\&O/DP Word, ICTSI and Dragados/CSAV) adopted this low tariff. Other bidders (SSA, HHLA, APM Terminals) decided to withdraw the $\$ 69$ offered. The only bidder to be eliminated in the first round was Hutchison, with a proposed per TEU tariff of $\$ 75.13$. Further detailing this concession example, the winner of the concession (DP World) offered 144m for it, compared with some $95.5 \mathrm{~m}$ from the second bidder (ICTI) and over $100 \mathrm{~m}$ in excess of the third one. This result led various parties to question whether there was an 'economic rationale' and conclude that the 'winner is not a winner'. ${ }^{15}$

Table 2. System for the calculation of the concession term as used by the Antwerp Port Authority

\begin{tabular}{|l|l|}
\hline Investment level & Term \\
\hline Investment $>=375 \mathrm{EUR} / \mathrm{m}^{2}$ of arable land & 40 years \\
\hline $225 \mathrm{EUR}<=$ investment $<375 \mathrm{EUR} / \mathrm{m}^{2}$ of arable land & 35 years \\
\hline $175 \mathrm{EUR}<=$ investment $<225 \mathrm{EUR} / \mathrm{m}^{2}$ of arable land & 30 years \\
\hline $150 \mathrm{EUR}<=$ investment $<175 \mathrm{EUR} / \mathrm{m}^{2}$ of arable land & 25 years \\
\hline $125 \mathrm{EUR}<=$ investment $<150 \mathrm{EUR} / \mathrm{m}^{2}$ of arable land & 20 years \\
\hline $100 \mathrm{EUR}<=$ investment $<125 \mathrm{EUR} / \mathrm{m}^{2}$ of arable land & 15 years \\
\hline $25 \mathrm{EUR} / \mathrm{m}^{2}<=$ investment $<100 \mathrm{EUR} / \mathrm{m}^{2}$ of arable land & 10 years \\
\hline $0 \mathrm{EUR} / \mathrm{m}^{2}<=$ investment $<25 \mathrm{EUR} / \mathrm{m}^{2}$ of arable land & Quarterly \\
\hline
\end{tabular}

Note: The total arable land is typically much smaller than the concessioned land as there are severe building restrictions on large parts of concessioned land.

Source: Antwerp PA 


\section{ENDNOTES}

${ }^{1}$ An earlier version of the paper won the Palgrave Macmillan-Maritime Economics \& Logistics Best Paper Award, 2008, at the International Association of Maritime Economists (IAME) 2008 Conference, 2-4 April 2008, Dalian China.

${ }^{2}$ However, even in the British case, where both the regulatory and port-ownership role of the public sector have been minimized, government influence is significant at various levels (national, regional or local) in port development (Gilman, 2004). Recent examples are the UK government decisions to grant approval for the London Gateway development and to reject the proposal for the expansion of the port of Southampton.

${ }^{3}$ Liquid bulk cargo ports often do not require large infrastructure investments and may simply consist of infrastructure to connect a ship at anchor through pipelines with storage facilities on shore. Containers require specialized gantry cranes and further maritime and hinterland infrastructures.

${ }^{4}$ This conclusion is irrespective of the way in which their performance was measured - throughput per quay metre, TEU per ship-to-shore gantry or TEU per hectare.

${ }^{5}$ The concentration of terminal operators may be considered as an effective means to counterbalance the power of liner shipping companies and alliances. On the other hand, the concentration is sufficiently large to question whether terminal operators have market power. EU competition regulations have affected Hutchison's expansion in North Europe, and it is likely that the regulatory authorities will also scrutinize future expansions by the major players carefully.

${ }^{6}$ See the general literature on concessions in infrastructure and the related (re)negotiation processes between public actors and private interests: Kerf et al, 1998; Guasch, 2004; Guasch et al, 2006.

${ }^{7}$ In several cases a minimum percentage of transhipment containers is also agreed in the concession contract.

${ }^{8}$ The nature of the container-handling business (notably the high fixed costs and lack of service differentiation, except in terms of location) in theory creates significant opportunities to improve service through co-operation. However, forms of operational co-operation in the market do not come about easily and they usually end up in mergers or acquisitions (Notteboom, 2002, Musso et al, 2001, Slack and Frémont, 2005).

${ }^{9}$ Terminal operators that operate more than one terminal in the same port area (each terminal with different concession stipulations regarding throughput guarantees) are very creative in redistributing volumes over the different terminals in order to meet minimum throughput guarantees and optimize terminal operations.

${ }^{10}$ Naftemporiki. Open Process targets 550 million euros investments. 8 November 2006.

${ }^{11}$ With H. Smits (Port of Rotterdam Authority CEO) stating that: "The new port area will therefore be truly sustainable. Without an assessment procedure in which consortia know that they are competing with each other for a highly coveted terminal, it is much more difficult to agree on both a good price and sustainable operations." In: PRA press release. Container terminal on Maasvlakte 2 goes to broad consortium, 11 July 2007.

${ }^{12}$ See: Lloyd's List. Morocco as a transhipment hub, 26 October 2005. Notably, Contship Italia, also runs transhipment facilities in Cagliari and Gioia Tauro as well as other Italian terminals in Livorno, La Spezia and Ravena, so shifting cargoes stands as a potential.

${ }_{13}^{13}$ Portworld. PSA and Hutchison vying for Turkish port. 3 May 2007

${ }^{14}$ Portworld. Hutchison wins bid for Turkish port. 4 May 2007.

${ }^{15}$ See: Port Strategy, August 2006. 